\title{
How does Violence Mean? Understanding Nigerian Civil War Poetry
}

\section{Ogaga Okuyade}

\section{(2) OpenEdition}

1 Journals

Electronic version

URL: https://journals.openedition.org/ces/5468

DOI: $10.4000 /$ ces.5468

ISSN: 2534-6695

Publisher

SEPC (Société d'études des pays du Commonwealth)

\section{Printed version}

Date of publication: 1 April 2012

Number of pages: 19-29

ISSN: 2270-0633

\section{Electronic reference}

Ogaga Okuyade, "How does Violence Mean? Understanding Nigerian Civil War Poetry", Commonwealth Essays and Studies [Online], 34.2 | 2012, Online since 19 April 2021, connection on 23 July 2021. URL: http://journals.openedition.org/ces/5468 ; DOI: https://doi.org/10.4000/ces.5468

\section{(c) (i) $\odot$}

Commonwealth Essays and Studies is licensed under a Licence Creative Commons Attribution - Pas d'Utilisation Commerciale - Pas de Modification 4.0 International. 


\section{How does Violence Mean? Understanding Nigerian Civil War Poetry}

Violence is a potent intensifier of artistic creation, as some of the finest imaginative compositions across the world derive their subject from war. Most writers recreate the theme of war because it gives them ample opportunity to demonstrate that literature and society operate in a symbiotic relationship. Invariably, war stories have the propensity to reinterpret history because writers create from excruciating experiences they are emotionally and physically involved in. Significantly, literature becomes a response to a definite historical and socio-political condition. The Nigerian Civil War, which ended in 1970, remains the most recreated historical phenomenon in Nigerian literature. This article, therefore, does not just re-examine war as a dominant theme in post-War Nigerian literature, but it also aims at rereading Nigerian Civil War poetry in order to appraise the idea of the nation fifty years after independence. It analyses $\mathrm{Ni}$ gerian Civil War poetry as a creative tool for understanding the project of a new Nigeria against the backdrop of self-rule.

Nigeria, today the most populous nation in Africa, has been involved in sporadic bouts of violence ${ }^{1}$ streaming from the wounds inflicted on some ethnic groups during the Nigerian Civil War (1967-1970) which broke out a mere seven years after the nation had obtained its independence from Britain. Appraised from the outside, the nation features among the most stable in the continent, especially because its government appears to be in control of the public sphere. ${ }^{2}$ This essay aims at re-examining Nigerian Civil War poetry in order to appraise the idea of the nation fifty years after independence. The poetry written in Nigeria over this period cannot be analysed without sustained references to the historical events that inspired it. As a result, this essay addresses Nigerian Civil War poetry as an instrument for reappraising the project of a new Nigeria against the backdrop of self-rule. Forty years after the war, many Nigerians still view the balkanization of the nation as a possible answer to the ethnic strife, religious oppositions and economic crises that have been undermining national unity. The 2011 General Elections which ushered in Dr Goodluck Jonathan are a case in point, as he is the first president from the Niger Delta region, a geopolitical zone usually described as the most marginalized and underdeveloped because of the neglect of successive Nigerian governments, regardless of the fact that the zone produces over $90 \%$ of Nigeria's foreign exchange earning through crude oil. Hostilities continue to mount with the passage of time, and the assertion of difference remains the most potent marker in the construction of a national identity.

1. By violence I am not just referring to war, but to the crimes of varied magnitude which different ethnic groups perpetrate to give expression to their discontent regarding what they often described as their marginalisation. Even the most privileged groups use violence to assert their superiority over minority groups.

2. Most of the contemporary theorisations of the public sphere are based on the positions expressed by Jürgen Habermas in The Structural Transformation of the Public Sphere. "Public Sphere" translates the German term Öffentlichkeit, a spatial concept including the social spaces or sites where meanings are articulated, distributed, negotiated and consumed, as well as the collective body - "the public" - constituted by and through this process (Negt and Kluge 210). 
The population groups that make up the Nigeria project have continued to use ethnic difference as a marker to define their positions in the lopsided Nigerian federation either as a minority or a majority, as Christians or as Muslims. After the war, these groups have continued to use the same argument to express their disenchantment with and frustrations about the asymmetric distribution of resources and power. For example, in the last ten years, the Biafran flag was hoisted on several occasions to indicate that the war has not ended. The Niger Delta remains a chaotic spot because of the agitation for resource control and the principle of derivation, coupled with the federal government's brutal tactics at peace building, which have led to the ransacking of numerous communities in the area. Boko Haram, a religious sect from the northern part of Nigeria has continued to test the resolve of the Nigerian government on the need to build or develop the nation according to Western priorities such as education, science and technology. Jos, a onetime tourists' delight, is now hemmed in by potholes and the scars of incessant ethno-religious feuds that have culminated in devastating attacks the bomb blasts of December 2010 and January 2012, this time in Abuja, readily come to mind. The murdering of several Youth Corpers ${ }^{3}$ in some parts of Northern Nigeria during the post-election crisis of April 2011 evinces how unacceptable the victory of President Goodluck Jonathan remains to some, the fate of the young victims, graduate students mostly from Southern Nigeria, being more evidence of the enduring opposition to the election of a President from the south. ${ }^{4}$

The incessant crises recorded in Nigeria since the Civil War have made the country a tinderbox ready to ignite: "the old animosities have not died away completely; instead the fighting has continued in an informal, less dramatic, less apparent form" (Oriaku 43). Perhaps the tragedy has not been documented enough for most Nigerians to understand the full import of a fratricidal war that continues to threaten the unity of the Nigerian people. Others ask how many wars Nigeria still has to fight to achieve political stability. This interrogation remains essential considering the favourable ear the Nigerian government lent to the admonition of former Libyan President, Colonel Gaddafi on the need for the Nigerian nation to break up along religious lines.

The Nigerian Civil War started as an ethnic discord among the elitist cadre of the Nigerian military, but most of those who fought that war responded as individuals dedicated to their ideology. Their moral fury was directed at those attempting to destroy a vulnerable nation held together by mutual suspicion and distrust. And most of them fought for national unity in a way that required sacrificing their own lives. The war dealt a deadly geopolitical blow to Nigeria. Nigerians continue to react to the events with deep-seated anger, others with silence, asserting their patriotism, but not without some puzzlement. Why did this happen? How could it have happened? How can we make sure that this will not happen again?

3. The National Youth Service is a one-year compulsory paramilitary training for university graduates under the age of 30. It is one of the numerous strategies the government deployed to keep Nigeria one after the 1967-1970 Civil War, as it is geared towards integrating young people into different cultures within Nigeria. During the latest General Elections, Youth Corpers were part of the ad hoc staff responsible for conducting the ballot.

4. The murderers, northern youths with some Muslims among them, were galvanized into action with the slogan "Bamu so harni, mai mu ke so, mu na so Buhari," i.e. "we do not want an infidel or an unbeliever, what do we want? We want Buhari." General Buhari is a Muslim from Katsina state who was the CPC Presidential candidate during the 2011 elections. 
This essay examines the poetry on the Nigerian Civil War "as veritable indices for the reading and understanding of the instability and volatility of the polity in Nigeria" (Nwankwo 6, emphasis mine). It is concerned with the didactic function of poetry because one of its cardinal aims is to caution the generation who did not experience the war about the danger of resolving socio-political tensions with violence. Although some of the poems are not explicitly about the war, they are concerned with its legacy. The war ended over forty years ago, but the poetry on the war remains a cultural artefact that keeps the memory of the war alive and also cautions Nigerians on the need to settle disputes through diplomacy, even those which have led to outbursts of violence. One is reminded of Wilfred Owens's admonition that "all a poet can do today is warn" (31). Starting from this premise, war poetry is not only a therapy; it also becomes a balm for the wounds of the past.

\section{Soldier-Poets on the War}

Quantities of books dealing with the Civil War are still being published in Nigeria, many years after the fall of Biafra. While few works examining the war appeared just after it ended, the dam seemed to burst in the 1980s and early 1990s when the trickle of publications became a spate. The war changed the men who had enlisted expecting a heroic experience but who were forever altered by the realities of war. These soldierpoets give eyewitness accounts of the horrors they underwent. Their testimonies are supposed to be admonitions to the generation who did not experience the crisis. Their poetry configures graphic, shocking images of the atrocities. Yet studies and criticism on Nigerian Civil War literature hardly pay any attention to the contributions of soldierpoets in the imaging of the war experience. This critical neglect may be attributed to the fact that most of the poems by soldier-poets hardly meet the artistic standards of established writers who recreated the experience of the war outside the barracks when considering the question of language and form. However, a critical study of the poetry written by infantrymen will demonstrate that some of the poems do not only capture the harrowing experiences of war, they also perform an important memorial function.

Voices from the Trench edited by Mamman Vatsa and War Cries by Domcat Bali gather together poems written by soldiers. Some of the men who contributed to Vatsa's collection may not have fought in the war, but as members of the military they understand the intricacies of a war situation. Olu Akinyode's "Sacrificial Lambs" examines the relationship between the gods and man. The "gods" in this context are the leaders whose unguided ambition for power and questionable sense of nationalism precipitated the crisis, even when they knew only too well that they would be observing the war from a distance. The poem describes soldiers as sacrificial victims to the bloodthirsty gods:

When the gods are annoyed with us,

We roast and turn to appease their anger.

Ready and alert, we must be

For days may come

To mount the alter and offer

A supreme price sacrifice (Vatsa 25)

The poem does not blame soldiers for their horrific war crimes. Instead, the ordinary soldier is viewed as overpowered by external forces, the victim of the bungled orders of the elitist cadre of the Nigerian armed forces who love to hold on to power for 
selfish reasons. The poem indicts uncaring or glory-seeking officers and politicians. In parallel, it exposes the tragic hardening that would affect anyone having to steel himself against daily atrocities.

Not only do soldier-poets on the war articulate the excruciating experience of war, but the evil and the absurdity of the enterprise also pervade their poetry. Major Attu's "Advance to Contact" asserts the vulnerability of man during war and the volatility of war. The situation is like the weather. It changes often. Victory smiles in the morning whereas in the evening the agony of defeat lurks around:

We moved ahead...

Every day

We died and lived

Till the end (Vatsa 43)

From Bali's account, there seems to be no complete victory in war. In "Assault Across the Niger" the bravado of the federal troops is celebrated, yet they suffer the setbacks of death as they "greedily went into town to loot" (32). Bali's style is descriptive; the poem reads like journalistic reportage because it gives a matter-of-fact, chronological account of the events.

I was gripped with fear as the

H-hour drew near,

And I began to shiver and perspire,

"You must control yourself," I thought in despair,

As I issued orders that were unclear...

Rat - tat - tat - tat - boom - boom - boom,

Rent the air as our guns released the bombs

To herald $\mathrm{H}$ - hour and spell doom

To whoever dared to be in the path (10)

Vivid details give access to the mind of the persona, calling attention to the disparity between his simulated outward bravado and internal psychic wrangling. Visual accuracy in the description of the images flashing through the persona's mind and his physical appearance give a documentary quality to Bali's poetry, as the lines carry the readers into the deserted streets, the soldiers' minds and their fields of fire.

Mamman Vatsa's "If I Must Die" echoes Claude McKay's "If We Must Die" and ridicules those who orchestrated the crisis. He satirizes the ignominy of those who engineered the war and forced "poor me/to shoot to kill/those against whom I have no ill" (128). Vatsa comments on the calibre of persons who begin wars, and their cowardice when the war becomes monstrous:

Wars are started by the mean

And left to be fought

By fools like me (Vatsa 29)

Ironically, after the war is lost and won, after cities have been ransacked and infantrymen have purchased victory with their blood, it is the generals and politicians who started the fire who will take the glory.

They zoom out in planes so to say out of rage and range of the guns

To countries strange 
Leaving me to die

Empty - like lie. (Vatsa 129)

History hardly remembers mere infantry soldiers, but generals always have their names in history books, because when they return, they "celebrate Thanksgiving Day," giving false accounts of their bravado during the war (Vatsa 128). "Rifleman's Song" is Psalmic in its tone and persuasive in its temper. It consists of a soldier's plea to his firearm. Vatsa here appreciates the fact that heroism is not exclusive. Even well-prepared soldiers need some luck to survive a war:

Rifle,

Steel-mate

Don't disappoint me $[\ldots]$

If you fire well

I can tell, $[\ldots]$

If you disappoint me

in war

Then I am dead. (192)

Vatsa's poems celebrate an ambiguous polarity. They illustrate the importance of patriotism and loyalty even if this means annihilating one's family, as long as it is a military order. "Soldier's Song" espouses this point. Invariably, it is only after the mindless rage of war that soldiers regret their disastrous actions. More importantly, Vatsa's poems demonstrate that survival in war is likely to depend on each man's luck. "That War Killed Him" and "They Died" are poems dedicated to Majors Umaro and Bugaje - two soldiers who fell when defending the integrity of their fatherland. After his demise, Bugaje has no place in memory or history. This form of erasure does not result from death, or even the absence of a grave, but from the fact that his loyalty and patriotism were forgotten. In addition to describing the despoliation of war and the insecurity it causes, Vatsa deals with issues related to the aftermath of the war. "God Forbid More Wars" and "Remembrance Day" are eloquent examples of his concern with the future of the nation. These poems lack the psychological depth, emotional carriage and the mood of despondency often found in aftermath poetry, but they are charged with the immediacy of war, thereby capturing the raw edge of each new day in times of war.

\section{Civilian Voices on the War}

Nigerian war poetry records this bleak period in Nigerian history with great emotional acuity, in a manner found in no other genre of writing. It also reveals the traumatic experience of Nigerians in turbulent times. Not only does Nigerian Civil War poetry abhor and condemn the unleashing of violence, it also empathizes with the population who suffered during and after the war. Although the poems are scattered in various anthologies and collections, they remain indelible traces of the integrity of the war experience.

Okigbo's "Path of Thunder" from the collection Labyrinths occupies an inaugural position in the literary production of the war poets. Okigbo gives us the first mapping of the topography of war while the generation that wrote after him broadened the horizon. Chidi Amuta remarks that war "puts the greatest pressure on human nature, relationships and institutions, it becomes also a fertile ground for the literary imagination" (186). Expressing the thoughts and feelings of soldier-poets as well as representing their 
own vision of the Civil War, these poems respond to the newness of a situation that stimulates artistic creation.

Although the experience of war is a disenchanting one and Civil War poetry reads like a jeremiad, poets strive to capture the conflict wholly, and their impulse to document the events is compounded with artistic concerns. Wole Soyinka expressed this succinctly as the ability of the poet to appropriate "the voice of the people and the full burden of their memory" (21). Alex Johnson remarked in addition that "because of the proximity of the experience, the deep passions engendered by events and the personal involvement of the individual do have a direct bearing on the artistic creation" (149). By the end of the war, the poets who recreated the war experience in their imaginative compositions did not only picture the absurdities of death in a time of war, they also broadened the horizon of Nigerian literature. Thus Nigerian literature developed a close relationship with history that is worth considering. Observing how these writers addressed the legacy of the war, one can therefore argue that a paradigm shift occurred in the development of Nigerian literature, one that may explain the present face of Nigerian poetry. The titles and themes of this new poetry emphasize a marked concentration on issues of national destiny. Nsukka, a town which, at that time, housed the only university in the Eastern region, fostered the emergence of the generation of poets that succeeded Okigbo. In his introductory note to Nsukka Harvest, a chapbook in which the university alumni and undergraduates expressed their grief, Chukwuma Azuonye explains that a sense of disgust over the waste the war engendered conditioned the imaginative creativity of the Nsukka poets in their reaction to the consequences of the conflict (1). The callous despoliation of the Nigerian people from their collective dream continues to haunt writings that express "the sadness of a generation whose life ambitions had been cut short by a sad and senseless war" (Azuonye 2).

Although the war was marked by the wanton destruction of lives and property, to Biafran writers war poetry symbolizes hope for a wounded society: "Biafran writers are committed to the revolutionary struggle of their people for justice and true independence" (Achebe, Morning 84). Questions therefore arise as to "how literary texts [are] perceived to pass meaning, and under which conditions [...] we attach meaning to them?" (Foulkes 20) The poetry of the Nigerian Civil War derives its preoccupations from an unmistakably real social context. This, in turn, sandwiches the poets between historical facts and aesthetic concerns, leaving them little room to mediate or negotiate a craft caught between the two poles of documentation and invention, especially as most Nigerians have first hand experience and knowledge of the war.

Achebe, whose oeuvre has long served to define the standard of innovation in African literature since the publication of Things Fall Apart, also wrote poetry steeped in the atmosphere of the conflict. "The First Shot" evokes the awfully languid process of maturation leading to war. Although a conflict may take time to erupt, it will soon become impossible to hold its seething violence in check:

That lone rifle-shot anonymous

In the dark striding chest-high

Through a nervous suburb at the break

Of our season of thunders will get

Sloop its flight and lodge

More firmly than the greater noises

Ahead in the forehead of memory. (Beware 11) 
This passage evinces both the immediate evil of the war and its far-reaching consequences. It suggests how wars begin with a single shot that eventually escalates into a full-blown conflict.

With Gabriel Okara, one of the most lyrical poets of the generation inspired by the Civil War, the surrealistic and philosophical dimensions that characterized his earlier writing were sidelined in favour of a more documentary approach in his war poems. Okara condemns the moral and psychological consequences of the war on individuals and society at large. In order to document this dark chapter in Nigerian history, his poetry transcends the private to assert the writer's social commitment. His "Silent Girl" addresses the moral and psychological consequences of the chaos caused by war. Dunbi Osani suggests that the poem presents time as a linear process: time past, time present and time future (135). The situation is so compelling that the horrific ambience of the war becomes stupefying, and the girl is unable to recall the moments of glory she once experienced. Okara refuses to romanticize the past because it is precisely the events of the past that have given birth to the atrocities of the present. Since past events have brought about an unbearable present, the poet advocates becoming disentangled from the past so as to secure a peaceful future which is only wished for, but not entirely within reach:

Let's break with the past that bred the present

and let today be reminder of tomorrow)

though tomorrow may only be a dream

as dream may vanish in our waking (44)

In spite of the persona's doubtful tone, the anticipation of a brighter tomorrow becomes a way of keeping faith in a moment of crisis, an effective strategy for sustaining hope. The agonies of the war also reverberate in "Rain Lullaby":

For now is not time for sleep or love

or tender emotions of days gone by

When the earth, sun and moon

Juggled night and day in my head

which now is home for vampires

and silent bats flitting from wall

to wall preying on my essence (46)

The difference between the past and the present is foregrounded through the poet's diction and the skilful use of imagery. The words "sleep," "love" and "tender" evoke a beautiful world now only existing in the past; while the images of "vampires" and "bats" index the overwhelming presence of evil, wickedness and terror during the war period.

Pol Ndu's style deftly articulates the fact that there is nothing poetic about war. The writing of this promising young poet, later to die in an automobile accident in 1976, bristles with interrogations over the signification of the conflict, the collapse of past aspirations and the need for fresh dreams. The themes of misery and pain loom large in numerous poems in Ndu's Songs for Seers. In "Evocation," the poet writes of the sinister aura surrounding threats of war:

Fire flakes

Rain with

Fire balls

The shrieking 
The sleeping

The naked

The ragged

The clothed

Melting

In the frenzy (20)

Nwachukwu-Agbada argues that the lack of punctuation in this poem is emblematic of "the speediness of war arsenal" (146). These lines capture the spate of confusion overwhelming the inhabitants of a town about to be lost to war. The rhythm of the lines is jumbled and jangled. Ndu uses line breaks to obscure the meaning of the poem. Often, such formal experimentations are designed to reflect the confusion experienced by soldiers and civilians alike. Ndu's incorporation of the contradictory elements in the structure of the poem encourages the reader to reflect on the chaos of the war.

Energy Crisis and Other Poems by Chinweizu also evokes the traumatic experience of war. Numerous poems in this collection capture the pain caused by chaos, the physical havoc the war brought about. "The Vanished City" describes the evacuation of people from their homes to become exiles in strange and foreign lands. The poem abounds in images of grief and death, as destruction swoops down on the city, now the object of a mindless rage. The last stanza refers to the state of emergency and shows a city on the verge of being destroyed:

City of the dead!

Dead city of the dead!

$[\ldots]$

Like a goat she died with her boast and fools.

Skeletons of mansions rattle the breeze

Under a coverlet of stars (51)

Obi Maduakor argues that J. P. Clark's poetry on the war addresses past trauma through images that help the persona envisage the war from a distance. To deal with chaos, Clark adopts a detached position in his accounts of the tragedy. Maduakor explains further that Clark's detached position is easily noticed because of the "disparity between mood (tone) and experience" (57). This may be because as a direct participant in the conflict, he saw some of his companions die before his very eyes, and he cannot quite muster the strength to translate their deaths into art. Clark transposes the experience of death into poetry through the selection and rearrangement of choice motifs, relying on descriptive details with searing emotional impact. As a result, Clark's poetry reads like a powerful indictment of the war. Irrespective of the sceptical distance they feign to assume, Clark's poems boldly denounce the destruction of national wealth and energy, the wrecking of an institution erected thanks to the toil of millions. His poems frown at the despoliation of the collective dream of the people of Nigeria. "The Causalities" reads like an indictment of the entire nation. Not only does the poem portray the futility of war, but it also denounces Nigeria's doomed history. Many years after the war, Nigeria has not yet been able to extirpate the roots of the conflict from its soil. Nigeria is not just a new territory witnessing the advent of new forms of poetry, the country has now entered the fraternity of war-torn nations. Clark captures this daunting sense of rejuvenation when he writes that: "we are characters now other than before" (85). 


\section{Post-War Poets}

The elusive relationship between history and the poet's imagination is the key to the universe of the Nigerian writers who began publishing a decade after the war ended. From the vantage point of the 1990s, when they started gaining recognition, it is surprising to note how many among them came to be obsessed by the memory of the Civil War, even in cases when they were too young to fight in it. For poets like Odia Ofeimun, the war experience was a harrowing one, forbidding him from ever moving "far away from this intense awareness of decadence" (Garuba 271). In "Where Bullets Have Spoken," Ofeimun gives us a vivid picture of fear, horror, and the expectations that arise in the wake of war:

And what prayers, pray, where bullets have spoken

a plague rolled by madmen to feed the eighty millions

what smile where dark craters have blighted

a sun that we had despaired of holding. (21)

Ofeimun's incantatory lines conjure up the atrocious ordeal the Nigerian population had to endure during these years. "Exodus 67" describes a situation of rampant anarchy, amplified through the repetition of the warning which serves as the poem's refrain: "the Iroko is spitting fire / if you have a child strap him to your bosom" (22).

Catherine Acholonu is one of the most vibrant female voices to have contributed to the wider diffusion and recognition of Nigerian war poetry. Although her writing does not display any marked difference from that of her male counterparts in terms of diction or imagery, her perspective on the war is clearly that of a woman. Her Nigeria in the Year 1999 is suffused with references to loss, rape, personal and collective angst. "Other Forms of Slaughter" insists that in times of war, women suffer the worst of physical, psychological and sexual abuse, as evinced by the images of abduction, rape and imprisonment abounding in the poem:

When innocent virgins

Basking in the sun

Suddenly wake up to

Greedy eyes

Lecherous tongues

And devouring breath (33)

The poem ends on an exclamatory note - "Yeah! These were other forms of slaughter" - which does not express triumph, but relief when the abuse comes to an end, although the survivors live to remember it. Sometimes death goes beyond the taking of a life. There are other kinds of deaths individuals suffer during war. Ode Ogede argues that "what makes 'Other Forms of Slaughter' so engaging is the alarming catalogue of the moral and physiological depravities" (92). When violence takes the better of man, he spurns the joy of peace and unleashes evil on his fellow man. Though the poet becomes incapacitated, he/she uses the craft of the imagination to sustain hope even in the midst of a crisis. Thus, Funso Aiyejina notes that "Acholonu employs the details of that dark period in Nigerian history in fashioning a comprehensive philosophy about oppression, dehumanization and the need to struggle in order to survive" (117).

It would be easy to conclude that the literature of war is about man's sense of destruction. However, the attempt to recreate the horrific event through an act of the imagination is a therapeutic one, because writing helps these poets and their audiences 
come to terms with the unspeakable. These poems are potent messages about the dangers of civil and national strife. Dale Ritterbusch argues that "loss in aftermath poetry is a given" because it is the only "given" about aftermath poetry (145). More compelling to this study is how Civil War poetry is about so much more than destruction and loss. It is about recovery, reclamation, revision and reckoning. This reassessment of Nigerian Civil War poetry amply demonstrates that there is nothing inspirational or fascinating about massacres. More importantly, the production of this period testifies to a paradigm shift in the history and development of Nigerian poetry which left behind themes that had dominated it until then - for instance, cultural clashes and conflicts, the lyrical musings of the pioneer followed by the second generation poets - and moved on to more topical, pressing issues involving the socio-political destiny of the nation. All the poems mentioned in this essay probe man's sense of destruction, and question whether the human imagination is strong enough to overcome perpetrated atrocities. These poems raise questions about the potential of art to communicate, or even transform the trauma of war into something meaningful. The war had led to the dismantling of Nigeria's socio-political achievements - the heritage of independence. Today's Nigeria is still struggling to come to terms with the consequences of the war.

Although writing the history of the war continues to be of paramount importance for Nigeria and its literature, Nigerians seem to have failed to recognize that the war is not only about disasters, but also offers opportunities for people to reassert their unity. Samuel Asein contends that the literary documentation of the war "can help to illuminate the dark recesses of the mind, and record not the tanks and the artilleries but the emotion, the suffering, the test of man which the crisis entailed" (166). Whether through eyewitness accounts by Nigerian infantrymen, Biafran soldiers, postmodern explorations, or the private diaries of nationalists and politicians, the literature of the Nigerian Civil war is an influential and increasingly popular category of contemporary literature. It has become so because the war extended the borders of Nigerian poetry. The war afforded Nigerian poets the opportunity to explore issues bordering on ethnicity and nationhood. Thus Nigerian poetry became inward looking - the poets began to deal with problems indicating that Nigerians, rather than colonialists, were responsible for the immediate post-independence crises. Invariably, Nigerian poetry after the Civil War expressed a widespread need for self re-appraisal.

One fact emerges from the corpus under study: whether written by soldiers who fought on the Federal side or by civilians, these testimonies hardly explore the question of victory and defeat. Neither do they pass any judgement on the fairness or even the necessity of the war. But they remain focused on the widening circles of pain radiating from loss. As a result, Nigerian Civil War poetry is not just about war. It is just as much about the nation and its people, the helpless witnesses of an era of violence. It represents the people in their resilience and resolution to erect a new nation on the ruins left by the war. War poetry thus constitutes the expression of a literary resistance to the chaotic state of affairs the Nigerian experience of war precipitated.

Ogaga OKuYade College of Education, Warri, Delta State, Nigeria 


\section{Works Cited}

Achebe, Chinua. Things Fall Apart. London: Heinemann, 1958.

—. Beware Soul Brothers: Poems. Enugu: Nwamife, 1972.

—. Morning Yet on Creation Day. London: Heinemann, 1977.

Acholonu, Catherine. Nigeria in the Year 1999. Owerri: Totan, 1985.

AiYejInA, Funso. "Recent Nigerian Poetry in English: An Alternative Tradition." Ogunbiyi, vol.1, 11228.

AмuтA, Chidi. "Literature of the Nigeria Civil War." Ogunbiyi, vol. 1, 85-92.

Asein, Samuel. "Literature as History: Crisis, Violence, and Strategies of Commitment in Nigerian Writing." Literature and Modern West African Culture. Ed. D. I. Nwoga. Benin City: Ethiope Publishing, 1978. 97-116

Azuonye, Chukwuma, ed. Nsukka Harvest. Nsukka: Odunke Publications, 1972.

BaLi, Domcat. War Cries. Lagos: Civilities Ltd, 1984.

Chinweizu. Energy Crisis and Other Poems. New York: Nok, 1977.

Clark, J. P. A Decade of Tongues. London: Longman, 1981.

Ezenwa-Ohaeto. "Pol Ndu." Ogunbiyi, vol. 2, 250-5.

Foulkes, A. P. Literature and Propaganda. London: Methuen, 1983.

GarubA, Harry. "Odia Ofeimun and Femi Fatoba." Ogunbiyi, vol. 2, 269-76.

HABERmas, Jürgen. The Structural Transformation of the Public Sphere - An Inquiry into a Category of Bourgeois Society. Cambridge, MA: The MIT Press, 1962.

Johnson, Alex. "Sunset at Dawn: A Biafran on the Nigerian Civil War." African Literature Today 11 (1980): 149-60.

Long, Richard A., and Eugenia W. Collier, eds. Afro-American Writing: An Anthology of Prose and Poetry. University Park, PA: Penn State P, 1985.

Maduakor, Obiajuru. "Violence as Poetic Focus: Nigerian Poetry and the Biafran Experience." Nsukeka Studies in African Literature 4 (1986): 53-70.

Negt, Oskar, and Alexander Kluge. Public Sphere and Experience: Toward an Analysis of the Bourgeois and Proletarian Public Sphere. Minneapolis: U of Minnesota P, 1993.

Nou, Pol. Songs for Seers. New York: Nok, 1974.

Nwachukwu-Agbada, J. O. J. "Songs from Thunder: Nigerian War Poetry." A Harvest from Tragedy: Critical Perspectives on Nigerian Civil War Literature. Ed. Chinyere Nwahunaya. Owerri: Springfield, 1997. 141-65.

Nwankwo, Chimalum. "The Muted Index of War in African Literature and Society." African Literature Today 26 (2008): 1-14.

Ofeimun, Odia. The Poet Lied. London: Longman, 1980.

OGEDE, Ode. "Exile and the Female Imagination: The Nigeria Civil War, Western Ideology (Feminism) and the Poetry of Catherine Acholonu." African Literature Today 22 (2000): 90-9.

Ogunbiyt, Yemi, ed. Perspectives on Nigerian Literature. Vol. 1 and 2. Lagos: Guardian Books, 1988.

OKARA, Gabriel. The Fisherman's Invocation. Benin City: Ethiope, 1978.

Okigbo, Christopher. Labyrinths. London: Heinemann, 1971.

Oriaku, Remy. "Continuing the Civil War by Other Means: Points of View in Selected Nigerian Civil War Memoirs." The Nigerian Civil War and its Aftermath. Ed. Eghosa Oseghae, Ebere Onwudiwe and Rotimi T. Suberu. Ibadan: John Archers, 2002. 41-50.

Osani, Dumbi. "Time and Change in Okara's Poetry." Uyo Journal of Humanities 11 (2006): 127-38.

Owens, Wilfred. "Preface." The Collected Poems of Wilfred Owens. Ed. C. Day Lewis. New York: New Directions, 1965.

Reuter, Yves. Introduction à l'analyse du roman. Paris: Bordas, 1992.

Ritterbusch, Dale. "Lessons Learned and Unlearned: The Aftermath Poetry of the War." The United States and Vietnam from War to Peace: Papers from an Interdisciplinary Conference on Reconciliation. Ed. Robert M. Slabey. Jefferson, NC: McFarland, 1986. 139-49.

SoYInKA, Wole. The Burden of Memory, the Muse of Forgiveness. Oxford: Oxford UP, 1999.

VATSA, Mamman, ed. Voices from the Trench. Enugu: Fourth Dimension, 1978. 